\title{
Structuring of a Haplortox by Cover Crops and Their Effects on the Yield of Soybean Grains
}

\author{
Guilherme Gabriel Ruffato ${ }^{1}$, Deonir Secco ${ }^{1}$, Luiz Antônio Zanão Junior ${ }^{2}$, Luciene Kazue Tokura ${ }^{1}$, \\ Aracéli Ciotti de Marins ${ }^{3}$, Bruna de Villa ${ }^{1}$, Amauri Ghellere Garcia Miranda ${ }^{2}$, Pablo Chang ${ }^{1}$, \\ Simone Andreia Roehrs ${ }^{1}$, Matheus Rodrigues Savioli ${ }^{1}$, Camila Nakoneczny Magalhães ${ }^{1}$, \\ Pedro Alexandre Develen Cardoso de Lima ${ }^{1}$ \& Laís Fernanda Juchem do Nascimento ${ }^{1}$ \\ ${ }^{1}$ State University of West Paraná, Cascavel, Paraná, Brazil \\ ${ }^{2}$ Agronomic Institute of Paraná, Santa Tereza do Oeste, Paraná, Brazil \\ ${ }^{3}$ Department of Mathematics, Federal Technological University of Paraná, Toledo, Paraná, Brazil \\ Correspondence: Bruna de Villa, State University of West Paraná, Rua Universitária, 2069-Jardim Universitário, \\ CEP: 85819-110, Cascavel, Paraná, Brazil. Tel: 55-453-220-3151. E-mail: bruna.devilla.58@hotmail.com
}

Received: December 22, 2018

doi:10.5539/jas.v11n5p309
Accepted: February 12, $2019 \quad$ Online Published: April 15, 2019

URL: https://doi.org/10.5539/jas.v11n5p309

\begin{abstract}
The intense agricultural machinery traffic over the plantation ground can lead the erosion and growth difficulty. The goal of this study was to evaluate the soya bean yield after the implantation of species named "recoverable", of soil structure. The experiment was developed in plots of $20 \mathrm{~m} \times 25 \mathrm{~m}$, located in the Agronomic Institute of Parana (IAPAR), in Santa Tereza do Oeste, Paraná. The plots were cultivated by direct sowing of the following species, considered as treatments: sunn hemp (Crotalaria juncea), rattlebox (Crotalaria spectabilis), velvet bean (Mucuna aterrima), pearl millet (Pennisetum glaucum), pigeon pea (Cajanus cajan), dwarf pigeon pea (Cajanus cajan) beside them no-tillage and no-cover crop planting traditional system (control). Soil samples were collected from $0-10 \mathrm{~cm}, 10-20 \mathrm{~cm}$, and 20-30 cm-layers with 4 repetitions on each treatment. Soil density and porous soil space were also determined. The plot yield of soybean grains was evaluated over an area of $4.5 \mathrm{~m}^{2}$ for each treatment and grain moisture corrected to $13 \%$. The treatments' mean yields were compared using the Tukey test at $5 \%$ probability. The dwarf pigeon pea and the rattlebox were the most efficient cover crops in the reduction of soil bulk density in 0-10 and 10-20 cm depths. The soybean grain yield did not differ between the evaluated treatments, possibly due to the good precipitation conditions during the soybean growing cycle.
\end{abstract}

Keywords: soil bulk density, no-tillage and no-cover crop planting system, soybean grain yield

\section{Introduction}

The search for an adequate management system has attracted interest from researchers and agricultural producers. A suitable system seeks to use the best cost-benefit ratio, better machine-ground interaction and soil preservation, and better production (Llanillo et al., 2006).

The no-tillage system (NTS) is the system that has been used in the region, since there is less soil disturbance and greater conservation of soil physical characteristics. According to Ferreira et al. (2011) a soil without its structure stable may present complications in plant growth and development.

The NTS aims at three aspects: conservation of the structure, elevation of organic matter, and possibility of crop rotation in short periods of the year. The absence of soil revolving, crop rotation and permanent soil cover with plants or cultural remains improve the soil structural condition. However, the use of soil under this management system is often associated with intense machine traffic, which contributes to altering the soil structural quality, which leads to increased compaction (Bergamin et al., 2010).

For Assis et al. (2009), the compaction can be defined as the alteration in the physical structure of the soil that reduces the internal spaces that are normally occupied by water and air, which according to Silva and Cabeda (2006) results in a cohesive mass in the soil matrix. This operation results in the expulsion of air from the pores, causing a rearrangement of the particles, making the soil denser and less porous (Curi et al., 1993). 
One of the ways to change the negative effects of soil compaction has been the use of soil cover crop species with a more vigorous and profound root system, which are able to reduce the density and increase the porous space.

The soybean crop (Glycine max (L.) Merrill), is one of the most cultivated crops worldwide. In Brazil, soybean cultivation was implemented over 50 years, and its production is mainly focused on oil and feed production (EMBRAPA, 2018). The soybean crop (Glycine max (L.) Merrill) is currently the main crop in Brazil. According to data from CONAB (2018), Brazil had a harvest in December with 119.43 million tons in 2018, in addition the country is consolidated as the second world soybean producer, with an average of $3500 \mathrm{~kg} \mathrm{ha}^{-1}$. Of this amount, the state of Paraná contributing with a harvest of approximately 19.00 million tons.

Thus, the objective of this work was to evaluate the impact of the use of plant species recovering soil structure, density and total porosity and its benefits on soybean grain yield.

\section{Material and Methods}

\subsection{Experimental Area}

The experiment was conducted at the Agricultural Institute of Paraná [Instituto Agronômico do Paraná- IAPAR], located at the Experimental station of Santa Tereza do Oeste-Paraná. The soil was an Oxisol, clayey texture, soft-wavy relief, and basalt substrate (EMBRAPA, 2013). The climate of the region was temperate mesothermic and humid, and classified Cfa type (Köppen).

The data on rainfall, minimum temperature, maximum temperature and average temperature during the development of soybean crop, from November 2014 to March 2015, are presented in Figure 1.

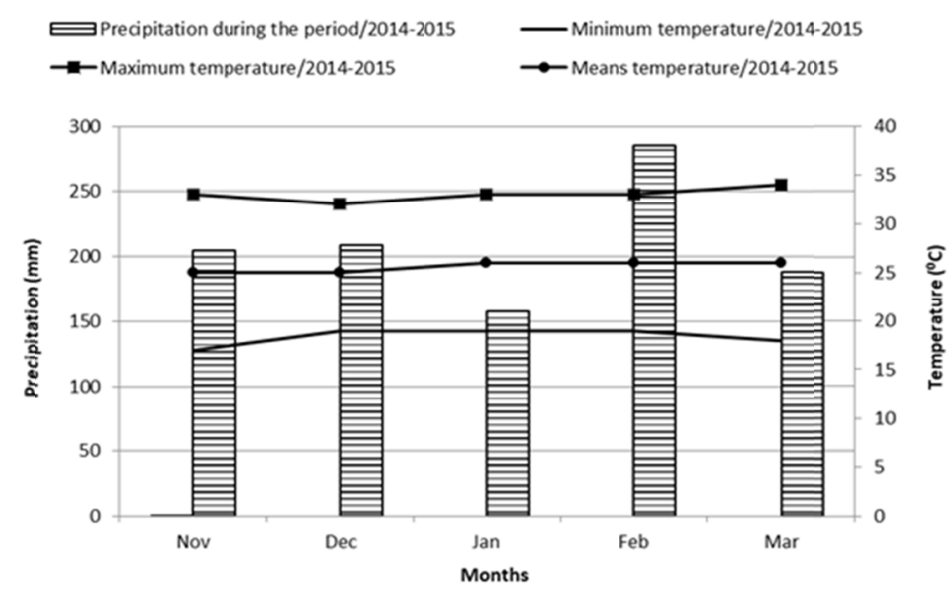

Figure 1. Rainfall, minimum temperature, maximum temperature and average temperature of soybean crop from November 2014 to March 2015

\subsection{Characterization of the Treatments and Experimental Design}

The experimental area consisted of seven plots, six plots with implantation of species called "reclaimers" of the structure: sunn hemp (Crotalaria juncea), rattlebox (Crotalaria spectabilis), velvet bean (Mucuna pruriens), pearl millet (Pennisetum americanum), pigeon pea (Cajanus cajan), dwarf pigeon pea (Cajanus cajan) In addition to the control (NTTS no-tillage and no-cover crop planting traditional system). The experimental plots were of $20 \mathrm{~m} \times 25 \mathrm{~m}$. The treatements were arranged a completely randomized block desing with 4 repetitions.

\subsection{Evaluation of the Treatments}

The undisturbed soil samples were collected from each of the 0-10;10-20, and 20-30 cm-layers, with two collection points and two repetitions per layer. Soil density and total soil porosity were determined in the Soil Physics Laboratory of the State University of Western Paraná, Cascavel Campus-PR.

The sowing of the soil cover species was carried out on March 27, 2014 in a no-tillage system. The management of the cover species occurred when the plants were in full bloom.

Soybean cultivar NK7059 (Vmax RR) was sown in the first week of November and the seeds were treated before sowing with $0.3 \mathrm{~L}$ of Cropstar $+0.3 \mathrm{~L}$ of Vitamax-Thiram for $100 \mathrm{~kg}$ of seeds. At sowing the spacing was 
$0.45 \mathrm{~m}$ between lines, totaling 16 seeds per linear meter. The fertilization was performed with application of 300 $\mathrm{kg} \mathrm{ha}^{-1}$ of the formulation $02-20-20$ of N-P-K.

The evaluation of soil density and that of porous space were performed according to the methodology recommended by EMBRAPA (2011).

The soybean grains harvest was performed manually on the 10/03/15, on 4 lines of 2.5 meters, with a spacing of $45 \mathrm{~cm}$ between lines, over 4 replications $\left(4.5 \mathrm{~m}^{2}\right)$ per plot. The seeds were cleaned, freed of all impurities, and their weight was corrected to $13 \%$ moisture.

\subsection{Statistical Analysis of the Data}

The analysis of variance for soil density and total soil porosity and the means of the treatments were compared by Tukey test at $5 \%$ probability were performed using the statistical program Sisvar (Ferreira, 2011).

\section{Results and Discussion}

The mean values of soil density and total soil porosity in the layers of $0-10 \mathrm{~cm}, 10-20 \mathrm{~cm}$, and $20-30 \mathrm{~cm}$-layers, under the cultivation of soil cover species, were presented in Tables 1 and 2, respectively.

Table 1 showed significant differences between cover crops for soil bulk density in the layers of $0-10 \mathrm{~cm}$ and $10-20 \mathrm{~cm}$. The smallest density values were observed for the dwarf pigeon pea $\left(0.87 \mathrm{Mg} \mathrm{m}^{-3}\right)$ in the $0-10$ $\mathrm{cm}$-layer and rattlebox $\left(0.98 \mathrm{Mg} \mathrm{m}^{-3}\right)$ in the 10-20 cm-layer, presenting a rapid restructuring capacity of the soil. Stone and Silveira (2001) also found significant differences in the soil density and total soil porosity working with different types of soil management system during the 3-year period. Spera et al (2004), also found differences in bulk density when conducting their experiments for 8 years in the production system of grain and forage crops under grazing, in a Latosol Typical dystrophic red, in Passo Fundo (RS). According to Camargo and Alleoni (1997), even the highest value of bulk density $\left(1.16 \mathrm{Mg} \mathrm{m}^{-3}\right)$ found in the present experiment was below the one considered harmful for root growth. For Reinert et al. (2008), there were deformations of the root system of the cover crops, between the values of 1.75 and $1.85 \mathrm{Mg} \mathrm{m}^{-3}$.

Table 1. Mean values of soil density under different cover crop species

\begin{tabular}{llll}
\hline \multirow{2}{*}{ Cover species } & \multicolumn{3}{c}{ Soil density $\left(\mathrm{Mg} \mathrm{m}^{-3}\right)$} \\
\cline { 2 - 4 } & $0-10 \mathrm{~cm}$-layer & $10-20 \mathrm{~cm}$-layer & $20-30 \mathrm{~cm}-$ layer \\
\hline Pearl millet & $1.04 \mathrm{ab}$ & $1.12 \mathrm{ab}$ & $1.04 \mathrm{a}$ \\
Dwarf pigeon pea & $0.87 \mathrm{~b}$ & $1.06 \mathrm{ab}$ & $1.01 \mathrm{a}$ \\
Sunn hemp & $1.11 \mathrm{a}$ & $1.16 \mathrm{a}$ & $0.98 \mathrm{a}$ \\
Pigeon pea & $1.03 \mathrm{ab}$ & $1.12 \mathrm{ab}$ & $1.02 \mathrm{a}$ \\
Rattlebox & $1.08 \mathrm{ab}$ & $0.98 \mathrm{~b}$ & $1.02 \mathrm{a}$ \\
Velvet bean & $1.01 \mathrm{ab}$ & $1.04 \mathrm{ab}$ & $0.97 \mathrm{a}$ \\
No-tillage and no-cover crop planting & $1.08 \mathrm{ab}$ & $1.08 \mathrm{ab}$ & $1.03 \mathrm{a}$ \\
traditional system (control) & & & \\
\hline
\end{tabular}

Note. Means followed by the same letter in the column are not significantly different.

Significant differences were observed for total soil porosity in the $0-10 \mathrm{~cm}$ and $10-20 \mathrm{~cm}$-layers (Table 2). Mazurana et al (2011) also found significant differences working on the same layers, when four management systems were studied including (i) no-tillage system, (ii) no-tillage system with scarification, (iii) management with scarifier hand roll destorroador, and (iv) scarification followed by grading in crop rotation for 7 years. The highest total porosity values were observed for the dwarf pigeon pea $(64.49 \%)$ in the $0-10 \mathrm{~cm}$-layer and Rattlebox $(64.80 \%)$ in the 10-20 cm-layer. According to the authors, the reduction may be associated with the performance of the different root systems of the crops that exploit the soil layers. For Andrade et al. (2009), soils with $50 \%$ of total porosity are considered ideal for agricultural production, thus, the values obtained were higher than those considered ideal, indicating that the roots system of these soil cover species promoted larger amounts of biopores for the successor culture. 
Table 2. Mean values of total soil porosity under different soil cover species

\begin{tabular}{llll}
\hline \multirow{2}{*}{ Cover species } & \multicolumn{3}{c}{ Total soil porosity (\%) } \\
\cline { 2 - 4 } & $0-10 \mathrm{~cm}$-layer & $10-20 \mathrm{~cm}$-layer & $20-30 \mathrm{~cm}-$ layer \\
\hline Pearl millet & $57.58 \mathrm{ab}$ & $59.77 \mathrm{ab}$ & $62.71 \mathrm{a}$ \\
Dwarf pigeon pea & $64.49 \mathrm{a}$ & $61.86 \mathrm{ab}$ & $63.64 \mathrm{a}$ \\
Sunn hemp & $54.85 \mathrm{~b}$ & $58.23 \mathrm{~b}$ & $64.50 \mathrm{a}$ \\
Pigeon pea & $58.23 \mathrm{ab}$ & $59.63 \mathrm{ab}$ & $63.38 \mathrm{a}$ \\
Rattlebox & $56.16 \mathrm{~b}$ & $64.80 \mathrm{a}$ & $63.12 \mathrm{a}$ \\
Velvet bean & $58.99 \mathrm{ab}$ & $62.39 \mathrm{ab}$ & $65.02 \mathrm{a}$ \\
No-tillage and no-cover crop planting & $56.07 \mathrm{~b}$ & $61.05 \mathrm{ab}$ & $63.16 \mathrm{a}$ \\
traditional system (control) & & & \\
\hline
\end{tabular}

Note. Means followed by the same letter in the column are not significantly different.

Table 3 shows the values related to the yield of soybean grains as a function of the different soil cover species.

Table 3. Yield of soybean grains as a function of soil cover species

\begin{tabular}{ll}
\hline Cover species & Grain yield $\left(\mathrm{kg} \mathrm{ha}^{-1}\right)$ \\
\hline Pearl millet & $3025.19 \mathrm{a}$ \\
Dwarf pigeon pea & $2944.11 \mathrm{a}$ \\
Sunn hemp & $2832.45 \mathrm{a}$ \\
Pigeon pea & $2760.74 \mathrm{a}$ \\
Rattlebox & $3035.22 \mathrm{a}$ \\
Velvet bean & $2911.95 \mathrm{a}$ \\
No-tillage traditional system (control) & $2672.25 \mathrm{a}$ \\
\hline
\end{tabular}

Note. Means followed by the same letter are not significantly different.

The results of grain yield of soybean crop showed no significant difference between the species of cover, possibly due to the good structural conditions of the soil and the climatic conditions which were favorable to the development of plants.

According to Embrapa (2011), the need for water that the crop needs for its productive potential is around 450 and $800 \mathrm{~mm} /$ cycle, depending on the species, climatic conditions, crop management and the duration of its cycle. And in the present work the precipitation was of 1,043 mm during the cycle of the soybean crop.

\section{Conclusion}

The dwarf pigeon pea and the rattlebox were the most efficient cover crops in the reduction of soil bulk density in $0-10$ and $10-20 \mathrm{~cm}$ depths.

The soybean grain yield did not differ between the evaluated treatments.

\section{References}

Andrade, R. S., Stone, L. F. S., \& Silveira, P. M. S. (2009). Cover crops and physical quality of a Latosol under no-tillage. Revista Brasileira de Engenharia Agrícola e Ambiental, 13(4), 411-418. https://doi.org/10.1590/ S1415-43662009000400007

Assis, R. L., Cargnelutti Filho, A., Lanças, K. P., \& Lazarini, G. D. (2009). Evaluation of soil resistance to penetration in different soils with varying moisture contents. Engenharia Agrícola, 29(4), 558-568. https://doi.org/10.1590/S0100-69162009000400006

Bergamin, A. C., Franchini, J. C., Souza, C. M. A., Souza, F. R., \& Vitorino, A. C. T. (2010). Induced compaction of a rhodic acrustox as related to maize root growth. Revista Brasileira de Ciência do Solo, 34(3), 681-691. https://doi.org/10.1590/S0100-06832010000300009

Camargo, O. A., \& Alleoni, L. R. F. (1997). Compactação do solo e o desenvolvimento das plantas. Piracicaba: ESALQ. 
CONAB (Companhia Nacional de Abastecimento). (2018). Acompanhamento da safra Brasileira, v.5-Safra 2017/2018-n.6. Sexto levantamento, Março 2018. Retrieved from http://www.conab.gov.br/OlalaCMS/ uploads/arquivos/18_03_13_14_15_33_grao_marco_2018.pdf

Curi, N., Larach, J. O. I., Kämpf, N., Moniz, A. C., \& Fontes, L. E. F. (1993). Vocabulário de ciência do solo. Campinas: Sociedade Brasileira de Ciência do Solo.

EMBRAPA (Empresa Brasileira de Pesquisa Agropecuária). (2011). Manual de métodos de análise de solos: Centro Nacional de Pesquisa de Solos. Rio de Janeiro: Embrapa.

EMBRAPA (Empresa Brasileira de Pesquisa Agropecuária). (2011). Tecnologias de Produção de Soja—Região Central do Brasil 2012 e 2013. Sistemas de Produção, 15, 84-88.

EMBRAPA (Empresa Brasileira de Pesquisa Agropecuária). (2013). Sistema Brasileiro de Classificação de Solos. Centro Nacional de Pesquisa de Solos (3rd ed.). Rio de Janeiro: Embrapa.

EMBRAPA (Empresa Brasileira de Pesquisa Agropecuária). (2018). Soja em números (Safra 2017/2018). Retrieved from https://www.embrapa.br/soja/cultivos/soja1/dados-economicos

Ferreira, D. F. (2011). Sisvar: A computer statistical analysis system. Ciência e Agrotecnologia, 35, $1039-1042$. https://doi.org/10.1590/S1413-70542011000600001

Ferreira, R. R. M., Tavares Filho, J., \& Ferreira, V. M. (2010). Effects of pasture system management on physical properties. Semina: Ciências Agrarias, 31(4), 913-932. https://doi.org/10.5433/1679-0359.2010v31n4p913

Stone, L. F., \& Silveira, P. M. (2001). Effects of soil tillage systems and crop rotations on soil porosity and bulk density. Revista Brasileira de Ciência do Solo, 25(2), 395-401. https://doi.org/10.1590/S0100-06832001 000200015

Llanillo, R. F., Richart, A., Tavares Filho, J., Fatima, M., \& Ferreira, R. R. M. (2006). Evolution of physical properties of soils according to tillage systems on annual crops. Ciências Agrárias, 27(2), 205-220. https://doi.org/10.5433/1679-0359.2006v27n2p205

Mazurana, M., Levien, R., \& Müller, J. C. (2011). Soil tillage systems: Changes in soil structure and crop response. Revista Brasileira de Ciência do solo, 35(4), 1197-1206. https://doi.org/10.1590/S0100-06832011 000400013

Reinert, D. J., Albuquerque, J. A., Reicher, J. M., Aita, C., \& Andrada, M. C. (2008). Bulk density critical limits for normal root growth of cover crops. Revista Brasileira de Ciência do Solo, 32(5), 1805-1816. https://doi.org/10.1590/S0100-06832008000500002

Spera, S. T., Santos, H. P., Fontanel, R. S., \& Tomm, G. O. (2004). Effects of grain production systems including pastures under no-tillage on soil physical properties and yield. Revista Brasileira de Ciência do Solo, 28(3), 533-542. https://doi.org/10.1590/S0100-06832004000300014

Silva, A. J. N., \& Cabeda, M. S. V. (2006). Soil compaction and compressibility parameters in relation to management systems and water content. Revista Brasileira de Ciência do Solo, 30(6), 921-930. https://doi.org/10.1590/S0100-06832006000600001

\section{Copyrights}

Copyright for this article is retained by the author(s), with first publication rights granted to the journal.

This is an open-access article distributed under the terms and conditions of the Creative Commons Attribution license (http://creativecommons.org/licenses/by/4.0/). 